\title{
Polycystic subdural hygroma associated with immunoglobulin G4-related intracranial hypertrophic pachymeningitis: a case report
}

\author{
Kazumichi Ota* ${ }^{*}$, Yoshihiko Nakazato, Risa Okuda, Ryu Yokoyama, Hitoshi Kawasaki, Naotoshi Tamura and \\ Toshimasa Yamamoto
}

\begin{abstract}
Background: Recent studies have examined hypertrophic pachymeningitis as an IgG4-RD. However, there are no reports of immunoglobulin G4 (IgG4)-related hypertrophic pachymeningitis with polycystic subdural hygroma.

Case presentation: A 56-year-old man presented to the hospital with complaints of a persistent, pulsatile, occipital headache and general malaise. Magnetic resonance imaging of the brain revealed hypertrophic pachymeningitis with polycystic subdural hygroma and hematoma. Based on the dural biopsy findings and exclusion of other diseases, the patient was diagnosed with immunoglobulin G4 (IgG4)-related hypertrophic pachymeningitis. IgG4related diseases may cause subdural hygroma more commonly than other diseases that cause hypertrophic pachymeningitis.

Conclusions: This is the first case report discussing polycystic subdural hygroma and hematoma with IgG4-related hypertrophic pachymeningitis.
\end{abstract}

Keywords: Hypertrophic pachymeningitis, IgG4-related disease, Polycystic hygroma, Hematoma

\section{Background}

Immunoglobulin G4-related disease (IgG4-RD) was first reported as hyper-IgG4emia in autoimmune pancreatitis [1]. In recent studies, the hypertrophic pachymeningitis spectrum has also been included in IgG4-RDs [2-4]. Several studies have been conducted to examine the clinical and imaging features of IgG4-related hypertrophic pachymeningitis [2-4]. However, there are no reports of IgG4-related hypertrophic pachymeningitis with polycystic subdural hygroma. This is the first case report of a polycystic subdural hygroma and hematoma with IgG4-related hypertrophic pachymeningitis.

\footnotetext{
* Correspondence: kota24@saitama-med.ac.jp
}

Department of Neurology, Saitama Medical University, 38 Morohongo Moroyama, Iruma-gun, Saitama 350-0495, Japan

\section{Case report}

A 56-year-old man with a history of asthma, sinusitis, serous otitis media, idiopathic eosinophilia, recurrent idiopathic myocarditis, and idiopathic interstitial pneumonia was treated with prednisolone (PSL) at a dose of $27.5 \mathrm{mg} /$ day. He had no symptom with steroid therapy. He complained of a persistent, pulsatile, occipital headache, and general malaise 2 weeks before admission, when the dose of PSL was reduced from $27.5 \mathrm{mg} /$ day to $22.5 \mathrm{mg} /$ day. However, he did not exhibit symptoms such as fever, weight loss, joint pain, rash, or diarrhea. A neurological examination revealed paralysis of the left abducens nerve. Magnetic resonance imaging (MRI) of the brain showed polycystic subdural hygroma and hematoma. In addition, with contrast enhancement, a

(c) The Author(s). 2020 Open Access This article is licensed under a Creative Commons Attribution 4.0 International License, which permits use, sharing, adaptation, distribution and reproduction in any medium or format, as long as you give appropriate credit to the original author(s) and the source, provide a link to the Creative Commons licence, and indicate if changes were made. The images or other third party material in this article are included in the article's Creative Commons licence, unless indicated otherwise in a credit line to the material. If material is not included in the article's Creative Commons licence and your intended use is not permitted by statutory regulation or exceeds the permitted use, you will need to obtain permission directly from the copyright holder. To view a copy of this licence, visit http://creativecommons.org/licenses/by/4.0/ The Creative Commons Public Domain Dedication waiver (http://creativecommons.org/publicdomain/zero/1.0/) applies to the data made available in this article, unless otherwise stated in a credit line to the data. 
diffuse thickening of the dura mater was observed (Fig. 1). Whole-body computed tomography (CT) scans showed no signs of lymphadenopathy or malignant tumors. Gallium scintigraphy revealed diffuse accumulation in the kidneys; however, there was no accumulation in the lymph nodes and joints. Urinalysis showed a tubular defect (N-acetyl-beta glucosamines $45 \mathrm{IU} / \mathrm{L}$, beta-2microglobulin $9156 \mu \mathrm{g} / \mathrm{L}$ ), suggesting interstitial nephritis. Microbial analyses and immunologic bioassays were uninformative. There was no complement consumption or eosinophilia. His serum IgG4 level was slightly increased $(126 \mathrm{mg} / \mathrm{dL})$ at the PSL dose of $22.5 \mathrm{mg} / \mathrm{dL}$. However, one year prior to the study, it was higher (332 $\mathrm{mg} / \mathrm{dL}$ ), although the dose of PSL was $7 \mathrm{mg} /$ day. Craniotomy was performed from the left side of the head with a burr hole, made a dural incision, and collected a sample. After biopsy and dural suture, it was confirmed that was no leakage of spinal fluid by the Valsalva test, preventing low intracranial pressure syndrome from occurring. Dural biopsy confirmed that the dura was $2 \mathrm{~mm}$ thick, and its surface was red and edematous, and very fragile. Histopathological examination of the surgical specimen revealed a fibro-inflammatory lesion in the thickened dura due to lymphoplasmacytic infiltrates. Immunohistochemical analysis showed lymphocytic infiltration, 60 IgG4+ plasma cells per high-power field, and an IgG4+/IgG ratio greater than 50\% (Fig. 2). There was no evidence of a malignant tumor, histiocytic disease, or granulomatous disease. Staining for microbial pathogens was negative. We established a diagnostic of IgG4-RD based on clinical diagnostic criteria $[5,6]$, we established a diagnosis of IgG4-RD; the unexplained multiple organ disorders (as mentioned before) also suggested IgG4-RD. The symptoms improved quickly with oral PSL therapy ( $45 \mathrm{mg} /$ day, $0.6 \mathrm{mg} / \mathrm{kg} /$ day) after 2 courses of methylprednisolone $1 \mathrm{~g}$ pulse therapy for 3 days, and the subsequent brain MRI showed complete regression of meningeal thickening, polycystic subdural hygroma, and hematoma. Thereafter, tacrolimus ( $3 \mathrm{mg} /$ day) was added, and the PSL dose was reduced by $2.5-5 \mathrm{mg}$ every two weeks to a final dose of $10 \mathrm{mg} /$ day. The patient had no recurrence of headache with oral treatment using PSL

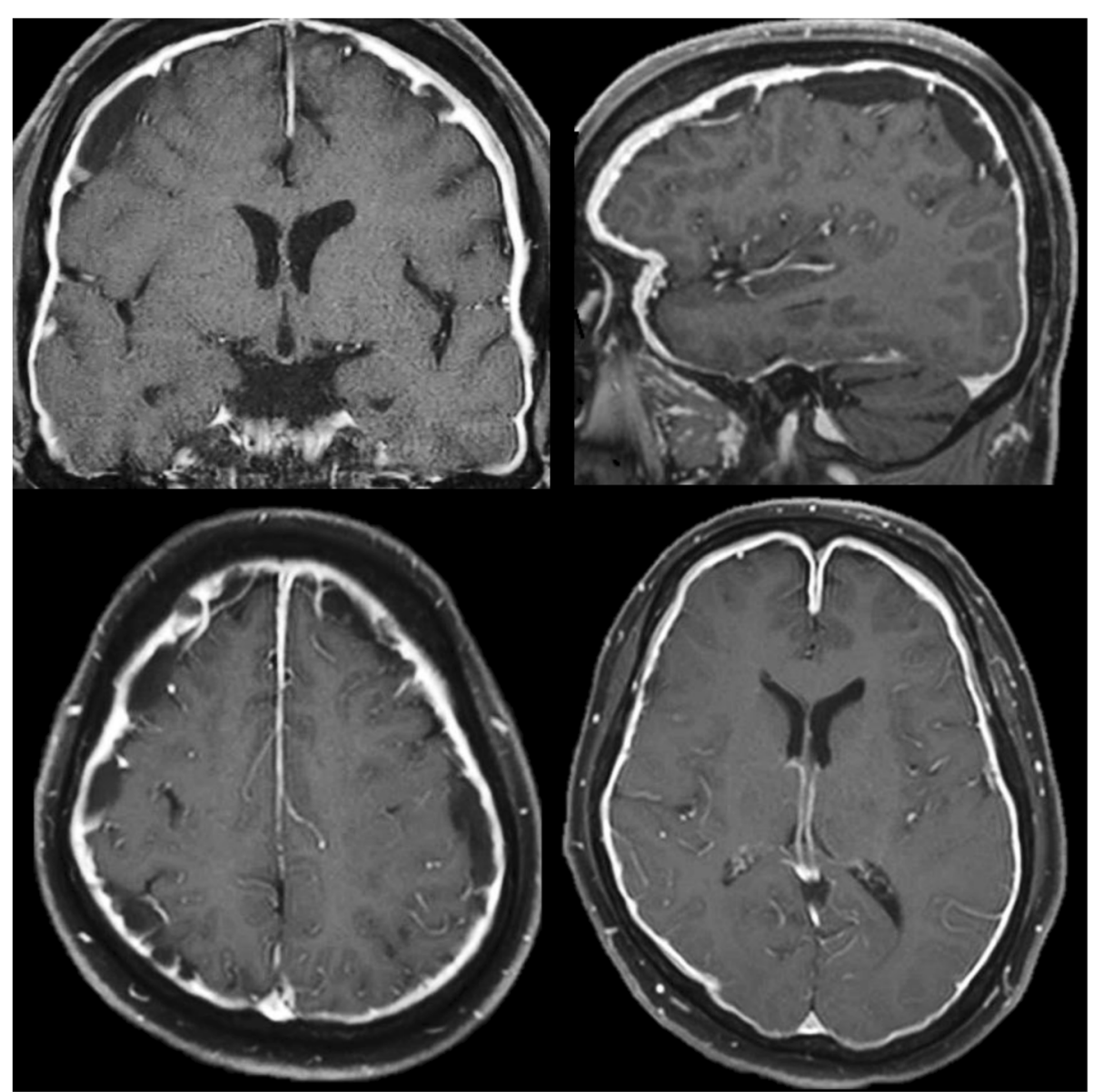

Fig. 1 Brain MRI (gadolinium enhanced T1-wighted images) on admission. MRI revealed polycystic subdural hygroma, hematoma, and diffuse thickening of the dura mater when probed using contrast enhancement (MRI, magnetic resonance imaging) 


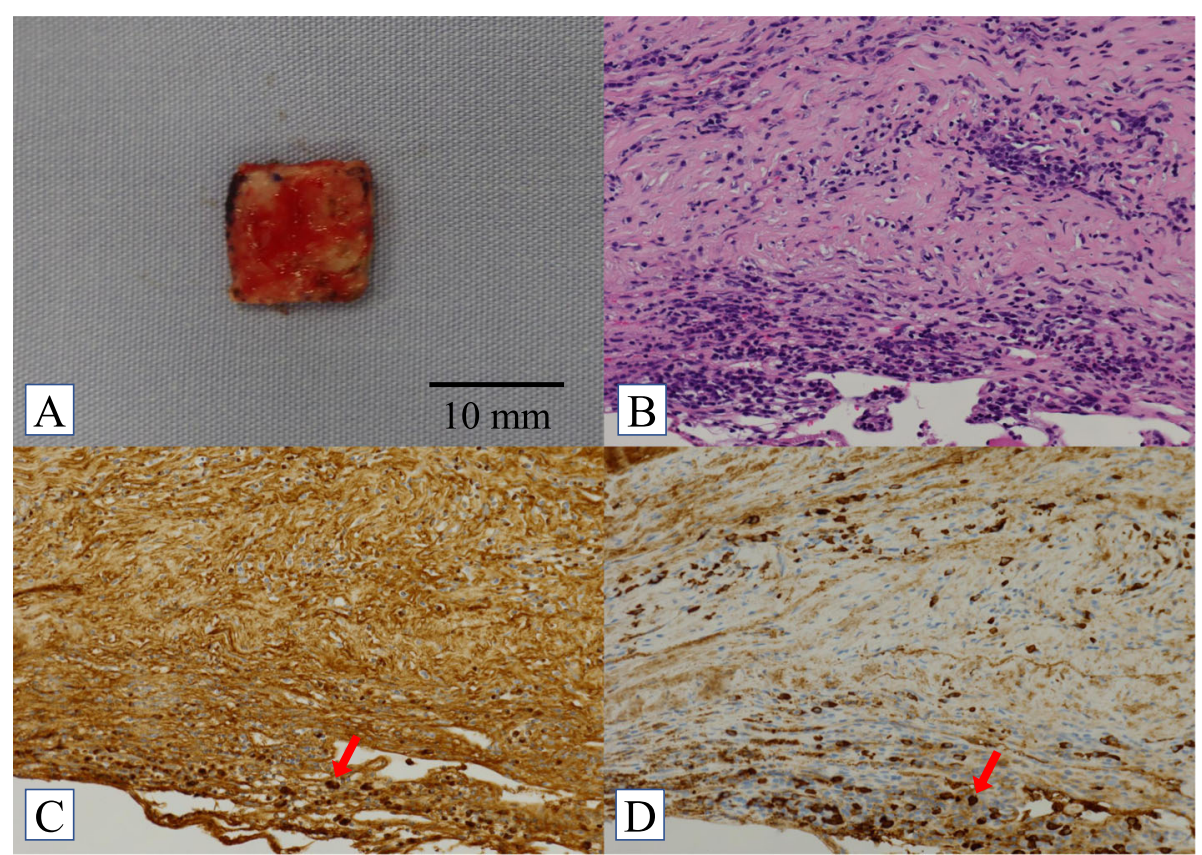

Fig. 2 Pathological findings. a: Macroscopic observation shows that the dura surface was red and edematous, and very fragile. b: The photomicrograph shows that the solid lesion consisted of proliferated fibroblast cells and infiltrated mononuclear cells, including predominantly plasma cells, with abundant collagenous tissue (H\&E; original magnification, $\times 400$ ). c and d: $\lg G(C)$ and $\lg G 4(D)$ staining revealed that most of the plasma cell infiltration into sclerosing lesions were IgG positive (IgG4-positive plasma cell/high power field, 60), and the ratio of IgG4-positive plasma cells (arrow) to the overall IgG-positive cells (arrow) is greater than 50\% in the area containing the highest infiltration of plasma cells (original magnification, $\times 400)(H \& E$, hematoxylin and eosin; lgG, immunoglobulin G)

(10 $\mathrm{mg} /$ day) and tacrolimus ( $3 \mathrm{mg} /$ day), and his serum IgG4 level decreased to $9.6 \mathrm{mg}$.

\section{Discussion and conclusions}

Intracranial hypertrophic pachymeningitis rarely accompanies subdural hygroma or hematoma. Only three cases have been reported in the literature $[7,8]$, including our case, of which two cases involved a diagnosis of IgG4RDs. Until now, there have been no reports of IgG4-RDs associated with polycystic subdural hygroma or hematoma. In our case, exudative retention due to strong inflammation of the dura may have caused reactive film formation bleeding from the capsule or bridging vein [7]. The dura adhesion may indicate that the exudate enters the space between the membranes and forms a cyst. In conclusion, we suggest that IgG4-RDs may often cause subdural hygroma.

\section{Abbreviations \\ IgG4: Immunoglobulin G4; IgG4-RD: Immunoglobulin G4-related disease; PSL: Prednisolone; MRI: Magnetic resonance imaging; CT: Computed tomography; H\&E: Hematoxylin and eosin}

\section{Acknowledgments}

We would like to thank Editage (www.editage.com) for English language editing.

\section{Consent to participate}

The patient provided consent for participation in the study.

\section{Authors' contributions}

$\mathrm{KO}, \mathrm{RO}, \mathrm{YR}$, and $\mathrm{HK}$ were involved in the study concept and design, collection of data, and drafting, reviewing, and critiquing the manuscript. YN was involved in the study concept and design, collection of data, drafting, reviewing, and critiquing the manuscript and supervision. NT and TY revised and critiqued the manuscript. All authors have read and approved the final manuscript.

\section{Funding}

Not applicable.

\section{Availability of data and materials}

The datasets used and/or analyzed during the current study available from the corresponding author on reasonable request.

\section{Ethics approval \\ $\mathrm{N} / \mathrm{A}$}

\section{Consent for publication}

Written informed consent was obtained from the patient for publication of this case report and any accompanying images. A copy of the written consent is available for review by the Editor of this journal.

\section{Competing interests}

The authors report no conflicts of interest.

Received: 22 April 2020 Accepted: 2 June 2020

Published online: 04 June 2020

\section{References}

1. Hamano H, Kawa S, Horiuchi A, Unno H, Furuya N, Akamatsu T, et al. High serum lgG4 concentrations in patients with sclerosing pancreatitis. N Engl J Med. 2001;344:732-8. 
2. Yonekawa T, Murai H, Utsuki S, Matsushita T, Masaki K, Isobe N, et al. A nationwide survey of hypertrophic pachymeningitis in Japan. J Neurol Neurosurg Psychiatry. 2014;85:732-9.

3. Cação G, Calejo M, Alves JE, Medeiros PB, Vila-Cha N, Mendonça T, et al. Clinical features of hypertrophic pachymeningitis in a center survey. Neurol Sci. 2019:40:543-51.

4. Melenotte C, Sequier J, Ebbo M, Kaphan E, Bernit E, Saillier L, et al. Clinical presentation, treatment and outcome of lgG4-related pachymeningitis: from a national case registry and literature review. Semin Arthritis Rheum. 2019; 49:430-7.

5. Deshpande V, Zen Y, Chan JK, Yi EE, Sato Y, Yoshino T, et al. Consensus statement on the pathology of IgG4-related disease. Mod Pathol. 2012;25: 1181-92.

6. Umehara H, Okazaki K, Masaki Y, Kawano M, Yamamoto M, Saeki T, et al. Comprehensive diagnostic criteria for lgG4-related disease (IgG4-RD), 2011. Mod Rheumatol. 2012;22:21-30

7. Miyazaki H, Tabuse M, Ishiyama N, Kikuchi R, Ogihara T, Nanki K. A case of multifocal fibrosclerosis presenting with chronic subdural hematoma. Brain and Nerve. 2011;63:795-9.

8. He Z, Ding F, Rong J, Gan Y. A case of idiopathic hypertrophic cranial pachymeningitis presenting as chronic subdural hematoma. J Zhejiang Univ (Med Sci). 2016:45:540-3.

\section{Publisher's Note}

Springer Nature remains neutral with regard to jurisdictional claims in published maps and institutional affiliations.

Ready to submit your research? Choose BMC and benefit from:

- fast, convenient online submission

- thorough peer review by experienced researchers in your field

- rapid publication on acceptance

- support for research data, including large and complex data types

- gold Open Access which fosters wider collaboration and increased citations

- maximum visibility for your research: over $100 \mathrm{M}$ website views per year

At $\mathrm{BMC}$, research is always in progress.

Learn more biomedcentral.com/submissions 